TP Periodica Polytechnica

Social and Management

Sciences

23(1), pp. 68-72, 2015

DOI: $10.3311 /$ PPso. 7724

Creative Commons Attribution (i)

RESEARCH ARTICLE

\section{Analysis of Public Transport Performance in Budapest, Hungary}

\author{
Gyula Gaal ${ }^{1}$, Eszter Horváth ${ }^{2}$, Ádám Török ${ }^{3 *}$, Mária Csete ${ }^{4}$
}

Received 24 September 2014; accepted after revision 18 November 2014

\begin{abstract}
In 2001 the European Commission defined the main rules of the expected changes of modal split in the White paper. Modal split is also a crucial question in urban areas, where transport has the greatest effects on living standards and environment. Due to the caused pollution, noise, health effects every stakeholder tries to make urban public transport as efficient as it is possible. This is a theoretical investigation which aims to analyze the production function of Budapest Public Transport in Hungary. In this paper the transport data of Budapest were used to create a model in which the effects of different production factors can be estimated and the public transport performance can be forecasted.
\end{abstract}

\section{Keywords}

modal split, public transport, Budapest, performance, forecast

\section{Introduction}

Transport system is a significant economic sector therefore society expects several positive effects, although the operation comes with several disadvantages. Transport helps to minimize the barriers of accessibility to goods and services, facilitates economic prosperity and efficient, coordinated and reliable movement. On the other hand, it has to actively contribute to environmental sustainability while providing effective integration and land use (IRJ, 2014).

Urban transport seems to be the most concerned subsector of the transport system, as most of the effects appear in cities and metropolitan areas. In 2050 , expectedly $70 \%$ of the population will be living in urban areas. "Today, 64\% of all travel kilometers made are urban and the amount of travel within urban areas is expected to triple by 2050." (Lerner, 2012). These are challenges for the near future as well therefore experts have to begin thinking of solving these problems which are partly recent bottlenecks but as time goes, they will define the level of standard more and more.

Recently the most important factors for the passengers are quality and costs (Tica et al., 2011), while performance and technology are also important attributes (Dell'Olio et al., 2012). However, spatial problems occur the most in these areas, consequently sustainability is recently the key for creating a popular public transport system (Cerny et al., 2014).

\section{Methodology}

$$
P=\frac{W}{t}
$$

where

P: $\quad$ Power $\left[\mathrm{J} \cdot \mathrm{s}^{-1}\right]$

W: Work $[\mathrm{J}]$

$\mathrm{t}$ : time $[\mathrm{s}]$

Based on the conventional physical theorem of power a similarity can be found with transport sector:

$$
P=\frac{W}{t}
$$


where

$$
\begin{array}{ll}
\mathrm{P}: & \text { Transport Performance [passenger } \bullet \mathrm{km}^{\bullet} \cdot \text { year }^{-1} \text { ] } \\
\mathrm{W}: & \text { Work [passenger } \bullet \mathrm{km}] \\
\mathrm{t}: & \text { time [year] }
\end{array}
$$

As can be seen from the above formula there is an analogy between the two phenomena. The definitions can be adequately used due to similarity in both scientific fields.

Modal share can be defined as the share of transport modes within the total performance. Although modal split integrates several factors, these numbers can highlight the existing problems and deeper analysis can help us to elaborate future strategies. Several researches were carried out which investigated various models of different fields of transport (Sivilevicius, 2011; David, Foucart, 2014). The modal split in Budapest is slowly decreasing in the previous years but it is very difficult to reverse the tendency. $60 \%$ of the citizens of Budapest chose public transport instead of individual transport (40\%). In the case of travels which cross the border of Budapest, the share is $39 \%$ and 61\% (individual is higher!) (Heinczinger et al., 2011).

In this paper authors investigated the performance of urban transport, based on the theorem of production functions. Production functions are generally describing the production mathematically (Muro, 2013; Pavelescu 2014; Torok and Torok, 2014). The general production function can be described as:

$$
T=f\left(M_{e}, M_{h}\right)
$$

where
$\mathrm{T}$ Production
$\mathrm{M}_{\mathrm{e}} \quad$ Human resource;
$\mathrm{M}_{\mathrm{h}} \quad$ Non-Human resource (i.e.: machines, money, etc.);

In case of urban transport human resource not only covers drivers, but traffic controllers, conductors as well. All urban transport related personnel must be considered. In case of urban passenger transport the well-known production function of Cobb-Douglas can be used:

$$
\mathrm{T}=c \cdot M_{e}^{x} \cdot M_{h}^{1-x}
$$

where

$\begin{array}{ll}T & \text { Production (Performance of urban passenger transport) } \\ M_{e} & \text { Human resource; } \\ M_{h} & \text { Non-Human resource (i.e.: vehicles); } \\ c & \text { index for technical development; } \\ \mathrm{x} & \text { Elasticity of human resource; } \\ 1-\mathrm{x} & \text { Elasticity of non-human resource. }\end{array}$

The Cobb-Douglas function is homogeneous, linear production function where the elasticity is constant over production. In urban transport - where theoretically the level of service needs to be increased continuously - the elasticity over production after certain level of development is not constant but decreasing. This is primarily related to the significant increase in capital intensity. In this concept the marginal substitution rate is very important. This shows how much one of the factor of production can be substituted by the other factor (in practice, the labor intensive work with machines). Further on, authors considered the production function with constant elasticity. According to the literature Cobb-Douglas production functions gives explanation $70 \%$ of total variance of production based on the production factors (Lin and Xie, 2014).

Technical development cannot only play an important role in development of vehicles, track or maintenance processes, but the labor and logistics can also be significantly developed. Sometimes even without investment or investment to processes that does not affect directly producing (eg. automation). Therefore a new form of Cobb-Douglas production function was derived (Jerzmanowski, 2007; Jarboui et. al., 2014) that can describe the evolution of production parameters, which are not lead to technical developed, but also take into consideration of dynamical changes of inputs (5):

$$
\mathrm{T}=(c \cdot e)^{w \cdot t} \cdot M(t)_{e}^{x} \cdot M(t)_{h}^{1-x}
$$

where

$t$ time of investigation;

w t parameter of neutral technical development.

In practice, in particular in technical-economic analysis the performance analysis of urban transport is essential. For instance the service level agreements are based on performance and have very strict regulation on production parameters (Sami et. al., 2013). According to the passenger transport performance these production parameters can be simplified. For instance in urban area the Eq. (5) can be modified as follow:

$$
\mathrm{T}=\mathrm{G} \cdot \mathrm{n}_{v} \cdot \mathrm{nt}_{v} \cdot \mathrm{v} \alpha \cdot \mathrm{q} \delta \cdot \mathrm{t} \tau
$$

where,

G vehicle fleet [-];

$\mathrm{n}_{\mathrm{u}} \quad$ worthiness factor $[-]$;

$\mathrm{n}$ number of working days;

$t_{n} \quad$ average daily working hours per vehicle [hour];

$\mathrm{v}_{\mathrm{a}} \quad$ average speed $\left[\mathrm{km} \mathrm{h}^{-1}\right]$;

$\mathrm{q}_{d} \quad$ average capacity of vehicles [person];

$t_{t} \quad$ loading factor $[-]$.

Databases have been built from public statistical data. These databases were contained the time series of input parameters. To analyze Eq. (6) a MATLAB Simulink model has been built. MATLAB Simulink environment is ensuring the usage of timeseries in case of input parameters and provide opportunity for the output parameter (public transport performance) to be defined also as time-series. Also the visualization of production function is available (Fig. 1): 


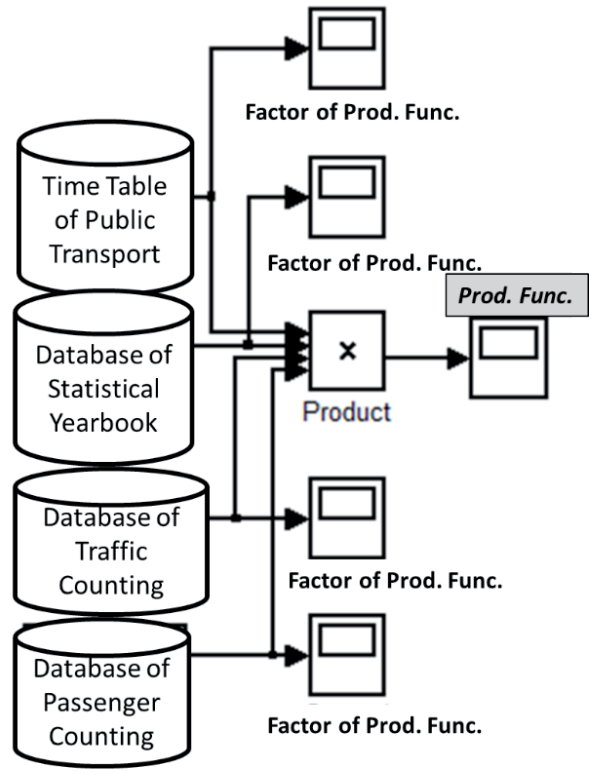

Fig. 1 Overview of MATLAB Simulink Modell (source: own creation)

The great advantage of the Simulink model that extrapolation based on BAU (Business As Usual) can be easily done not only for output parameter but for input production parameter as well. Visualization and analysis of each parameters (inputs and outputs) were done. Therefore in the timescale not the years were shown but the elapsed years since 2006 .

\section{Results}

The preliminary results of this model were presented at conference of innovation and sustainable surface transport (Gaal et. al., 2014). The previously presented model has been extended with the "Business As Usual" forecasting module, therefore more detailed results and analysis can be obtained. Firstly, of all the input parameters will be analyzed.

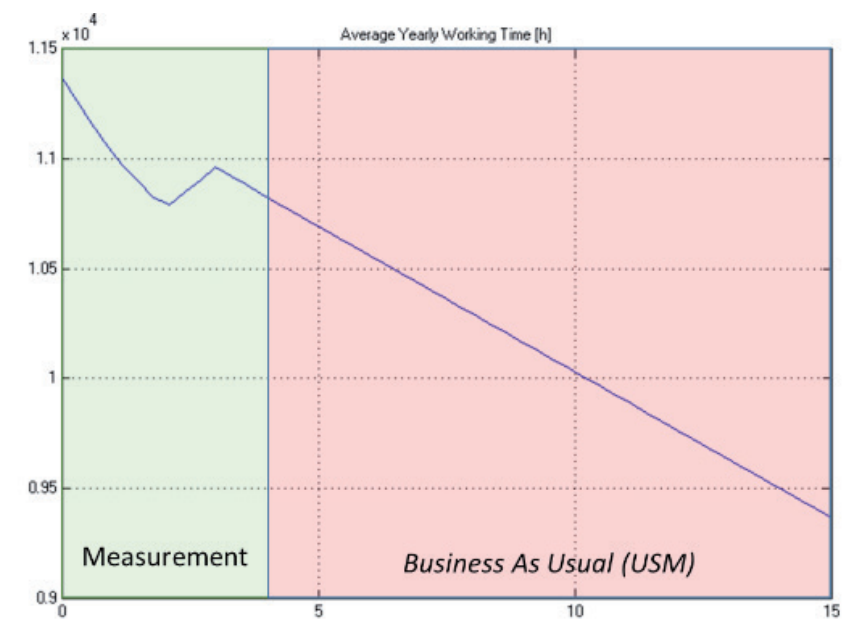

Fig. 2 Overview of input parameters - Average Yearly Working Time

As it can be seen (Fig. 2) average yearly working time has a significant decrease over time that has been extrapolated over the investigated time period. A small increase can be observed due to the new night bus services. In 2008, a major modification was done in the network. On one hand, many of the routes changed, new services appeared. On the other hand, the night service network also changed. While it was not taken into consideration before, from 2008, the new night network appeared in the statistical methodology. However, it does not change significantly the tendency. From 2004 to 2006, 150 new buses arrived in Budapest, which is more than $10 \%$ of the total number of vehicles. Also in 2006 and 2007, all 40 Combino trams arrived (see later) (BKV, 2010). For high performing cities the next step must be to fully integrate the travel value chain, increasing convenience by aggressively extending public transport.

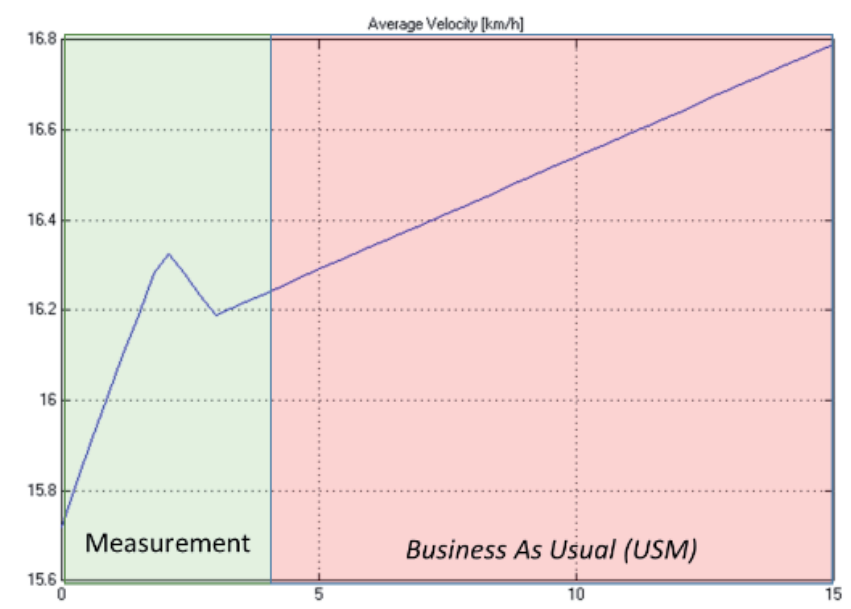

Fig. 3 Overview of input parameters - Average Velocity

As it can be seen (Fig. 3) average velocity has a significant increase over time that has been extrapolated over the investigated time period. A small decrease can be observed due to the increased urban traffic but the economic crisis brought much less transport demand and consequently less traffic, less car usage, therefore velocity of public transport vehicles (especially buses and trolley buses and partly trams) could increase further. Cities in mature countries with a high proportion of motorized individual transport need to fundamentally redesign their mobility systems so that they become more consumer and sustainability orientated.

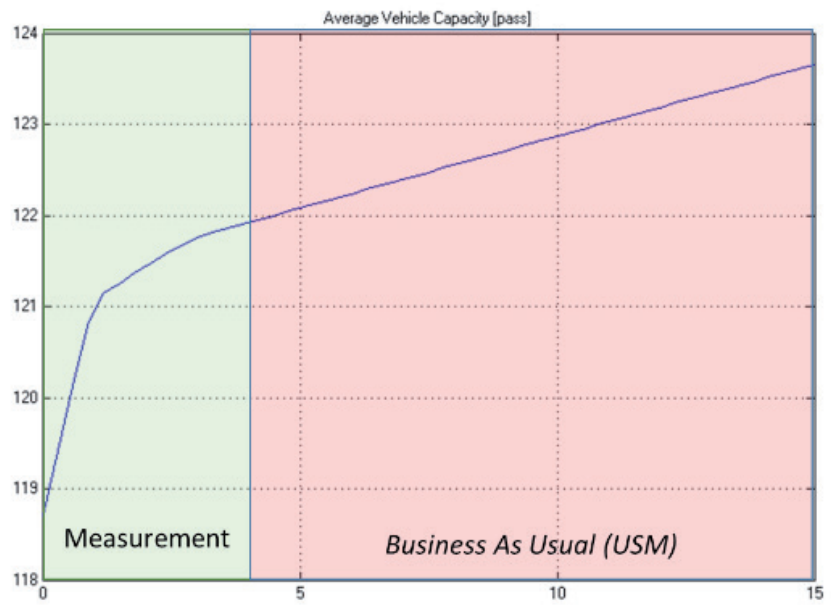

Fig. 4 Overview of input parameters - Average Vehicle Capacity 
As it can be seen (Fig. 4) average capacity has a significant increase over time that has been extrapolated over the investigated time period. A continuous increase can be observed due to the vehicle renewal program of Budapest. The above mentioned Combino trams are the longest trams in the world, consequently the 40 new vehicles meant a definite increase in vehicle capacity (one Combino can transport 350 passengers, while an articulated bus can serve about 100 passengers). On the other hand, it has to be mentioned that parallel with this tendency, the total number of vehicles decreased in the analyzed period.

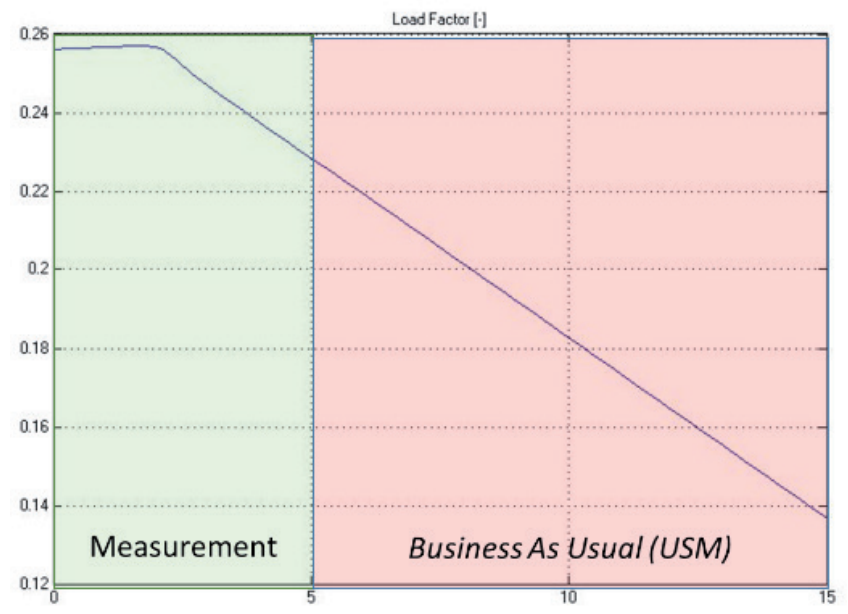

Fig. 5 Overview of input parameters - Load Factor

As it can be seen (Fig. 5) load factor has a significant decrease over time that has been extrapolated over the investigated time period. A continuous decrease can be observed in the recent years. Still, the new network in 2008 brought easily noticeable change in the tendency but the effects of the beginning economic crisis can be realized as well. Also, it has to be added that load factor is strongly depending on geographic position and timing.

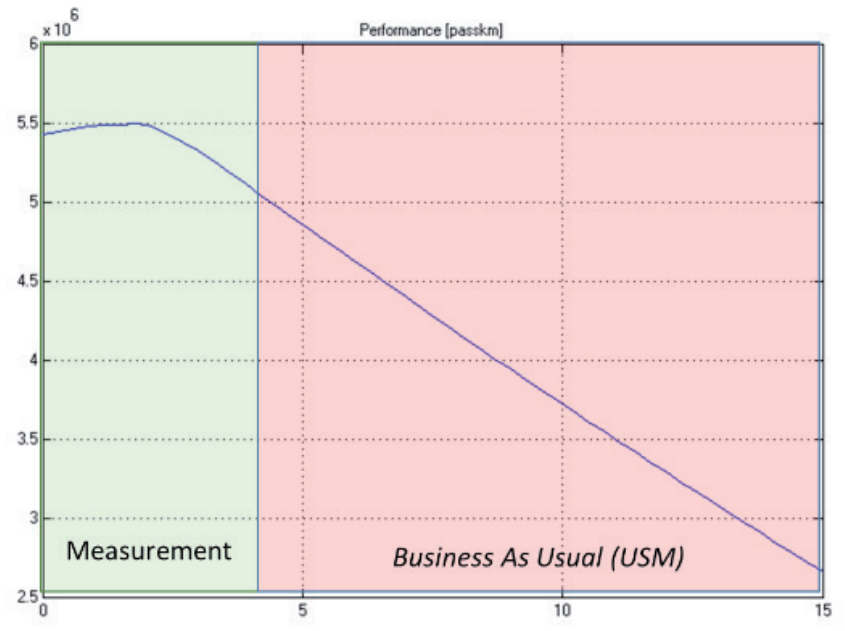

Fig. 6 Overview of output parameter - Performance

\section{Conclusion}

The described analysis can help to discover some general properties and characteristics of public transport operations. The analysis of the performance of public transport with production function can lead to results that has direct practical relevance on transport policy on political decision making. The results can support some practice oriented arguments such as development of vehicle fleet, average daily working hours per vehicle or loading factor. Therefore direct application of the results is possible. The reform of urban mobility systems is one of the biggest challenges confronting policymakers, stakeholders and users. Although there is strong economic, political and social effort to slow down the decrease of modal split, the currently analyzed tendency shows different way. Increase in modal share, in public transport performance would mean to have increased proportion of public transport compared to individual modes. Therefore environmental surplus can be gained. Modal split is a crucial indicator for evaluating the sustainability of urban public transport systems. According to the results the current path of Hungarian public transport in Budapest is unsustainable and would lead to the abandon of public transport.

\section{References}

BKV Zrt. (2010) Éves jelentés. (Annual reports of BKV PLC). [Online] Available from: http://www.bkv.hu/hu/kiadvanyaink/ [Accessed: 20 June 2014] (In Hungarian)

Cerny, J., Cerna, A., Linda, B. (2014) Support of decision-making on economic and social sustainability of public transport. Transport. 29 (1). pp. 59-68. DOI: $10.3846 / 16484142.2014 .897645$

Commission of the European Communities: White paper. European transport policy for 2010: time to decide. $\operatorname{COM}(2001) 370$ final. Brussels. 12.9.2001. [Online] Available from: http://ec.europa.eu/transport/themes/ strategies/doc/2001_white_paper/lb_com_2001_0370_en.pdf [Accessed: 19 June 2014]

David, Q., Foucart, R. (2014) Modal choice and optimal congestion. Regional Science and Urban Economics. 48. pp. 12-20. DOI: 10.1016/j.regsciurbeco.2014.04.005

Dell'Olio, L., Ibeas, A., Dominguez, A., Gonzalez, F. (2012) Passenger preference analysis: light rail transit or bus versus car. Transport. 27 (3). pp. 276-285. DOI: 10.3846/16484142.2012.719839

Gaal Gy., Horváth E., Csete M., Török Á. (2014) A budapesti közösségi közlekedés teljesítményének vizsgálata. (Performance analysis of public transport in Budapest.) In: Innováció és fenntartható felszini közlekedés konferencia. (Conference of Innovation and Sustainbale Surface Transport.) Budapest, Hungary, Aug. 25. 2014 - Aug .27. 2014, Paper 12. 4 p. ISBN:978-963-88875-3-5 (in Hungarian)

Heinczinger, M., Gaal, Gy., Török, Á. (2011) A közösségi közlekedés arányának növelése Budapest közlekedésében. (Increasing modal split in Budapest.) Európai Tükör. 16 (5). (In Hungarian)

IRJ (2014) Urban networks under pressure. International Rail Journal. 54 (6). pp. 40-43.

Jarboui, S., Forget, P., Boujelbene, Y. (2014) Transport firms' inefficiency and managerial optimism: A stochastic frontier analysis. Journal of Behavioral and Experimental Finance. 3. pp. 41-51.

DOI: 10.1016/j.jbef.2014.07.003 
Jerzamanowski, M. (2007) Total factor productivity differences: Appropriate technology vs. efficiency. European Economic Review. 51 (8). pp. 2080 2110. DOI: 10.1016/j.euroecorev.2006.12.005

Lerner, W. (2012) The future of Urban Mobility. [Online] Available from: http:// www.adlittle.com/downloads/tx_adlreports/ADL_Future_of_urban_ mobility.pdf [Accessed: 25 June 2014]

Lin, B., Xie, C. (2014) Energy substitution effect on transport industry of Chinabased on trans-log production function. Energy. 67. pp. 213-222.

DOI: 10.1016/j.energy.2013.12.045

Muro, K. (2013) A note on the three-sector Cobb-Douglas GDP function. Economic Modelling. 31.pp. 18-21. DOI: 10.1016/j.econmod.2012.11.008

Pavelescu, F. M. (2014) Methodological Considerations Regarding the Estimated Returns to Scale in Case of Cobb-douglas Production Function. Procedia Economics and Finance. 8. pp. 535-542.

DOI: $10.1016 / \mathrm{S} 2212-5671(14) 00125-7$
Sami, J., Pascal, F., Younes, B. (2013) Public Road Transport Efficiency: A Stochastic Frontier Analysis. Journal of Transportation Systems Engineering and Information Technology. 13 (5). pp. 64-71. DOI: 10.1016/S1570-6672(13)60123-3

Sivilevicius, H. (2011) Modelling the interaction of transport system elements. Transport. 26 (1). pp. 20-34. DOI: 10.3846/16484142.2011.560366

Tica, S., Filipovic, S., Zivanovic, P., Bajcetic, S. (2011) Development of trolleybus passenger transport subsystems in terms of sustainable development and quality of life in cities. International Journal for Traffic and Transport Engineering. 1 (4). pp. 196-205.

Török, Á., Török, Á. (2014) Macroeconomic analysis of road vehicles related environmental pollution in Hungary. Central European Journal of Engineering. 4 (2). pp. 186-191. DOI: 10.2478/s13531-013-0147-0 